\title{
Deregulation and Tertiary Education in Nigeria: Implications for National Development.
}

\author{
Dr. Aiya, Fidelis \\ Dept of Public Administration, Faculty of Management Sciences, Ambrose Alli University, Ekpoma-Nigeria
}

\begin{abstract}
The study investigated the perceived impact of government policy of deregulation on tertiary educational system in Nigeria. Edo state was taken as the case study. A total of 881 respondents provided responses that were used for analysis. Data analysis was accomplished using frequency tables, mean and Friedman test.The respondents felt the enactment of the policy was borne out of government inability to fund tertiary education development (mean $=3.45$ ) and called for stricter issuance of licensing (mean $=3.37$ ). In the opinion of the respondents, deregulation of the tertiary educational system has had important positive and negative impacts on the educational sector. Notable positive impacts included increased students enrolment or admission into tertiary institutions in the country (mean $=4.58$ ), and improved infrastructural development (mean $=4.00)$. The major negative impacts of the deregulation bordered on increased unemployment among university graduates (mean $=3.99$ ) and compromised admission process/procedures employed by private tertiary institutions (mean $=3.91)$. Friedman test showed that significant differences exist in the perceived impact of the deregulation of the tertiary education sector.Based on the findings the author recommends among others that; government should exercise closer monitoring of institutions with license to operate private universities; government should also expand the industrial development to encourage employment and,the officers of the quality control agencies should be encouraged to maintain professionalism in the conduct of their exercise.
\end{abstract}

Key words: deregulation, education, policy, government, Nigeria,regulation

\section{Introduction}

In the past decades, education was conceived as one of the social services provided by the government for relative affordibility among the people, based on the popular belief that education is an engine of growth and poverty alleviation. However, in the recent period, as a part of structural reform (Ubhenin,2012;Harns, 2003 and Demurger, 2001) deregulation, privalization, commercialization among others were introduced by International Monetary Fund(IMF) and the World Bank as prescription for their macroeconomic distortion that griped the third world states particularly Nigeria in the 80s. Against this background the federal government of Nigeria on this melliu, embacked on deregulation process in some sectors which include; petroleum, telecommunication, education and power sector as the most recent .

In setting the tune of this discussion, one may ask, What is Deregulation? Deregulation as a concept has attracted several meanings from the point of view of academias and political actors in shaping the debate.

Deregulation presupposes the existence of regulation.The implication being that a deregulated system emerges from a pre-existing regulated structure. In a regulated system, government determines the market forces of demand and supply. Underregulated situation, government is the single actor in determining what is obtainable in market environment. Thatis, what to be produced, prices, quantity and quality of such product.To deregulate therefore simply means to be made free from such regulated situation. Oluleye (2005) defined deregulation as a process of removing the controls and restrictions which the government imposes on the economy and businesses of all kinds. That is, turning a regulated economy to a free market system, where the sovereignty of the forces of demand and supply can determine real market situation.

Cosely related to Oluleye's conception is Arthur and Sheffrin(2002), when they see deregulation as the removal or simplification of government rules and regulations that constrain the operation of market forces. Simplification of government rules and regulations as used by Arthur and Sheffrin denotes that deregulation does not presupposes elimination of law against the fraudulent practices in the economic terrain but reduction of government control in the management of businesses that could bring about free market environment. The conceptual ascertion of Gbosi(2004), coroborrates with that of Arthur and Sheffrin when he opines that "deregulation does not mean the absence of regulation rather, it means the deliberate informed process of removal or mitigation of restrictions which are obstacles or non deterministic and tend to reduce efficiency or competitive equities"

Onwuka, Asemota and Arowoshegbe (2005) in their study; "Deregulation - poverty Alleviation nexus in Nigeria", showed that deregulation has increased the level of poverty in Nigeria. According to them, 
globalization brought about increase in the prices of imported goods as well as in the level of unemployment due to retrenchments. They further reported in their findings that the impact of deregulation on fertilizer has led to increase in the price of food items thereby creating room for scarcity. Another area of the impact of deregulation as revealed in their study is high level of inflation. They concluded in their findings that deregulation asfight against poverty may likely not yield the desired results. In a general term, deregulation intensified poverty in Nigeria.

Onobun and Obadan (2005), held a contrary view against Onwuka el ta,when they(Onobun and Obadan) asserted that a well managed deregulation will bring about prosperity among Nigerians, since it will bring about productive competitiveness among business men which will enhance business performance to the levelof higher productivity and efficiency. Beyond this prosperity envisaged by them, is the danger of badly managed deregulated economy that will bring about corrosive effect on humanity and poverty, as witnessed in the deregulation of the down- stream sector of the oil industry that led to an increase in the prices of petroleum products that consequence a general increase in prices of goods and services in Nigeria.Iyoha(1999), asserted that the contributory factor to the high rate of inflation in 1991 was the withdrawal of petroleum subsidies which resulted in higher transportation cost. This particularly brought a devastating effect to the rural dwellers (farmers and other inhabitants). According to Iyoha (1999), this situation further impoverished the rural people.

Omoike and Uwaiye (2005) on deregulation of education in Nigeria: implication for access to university education, posited that such deregulation will bring about a sharp increase in school fees. This will lead to a high number of university drop out, as it will affect the low-income earners access into public university in Nigeria. Since deregulation means removal of government subsidies, bursary awards, scholarships and loans schemes will not be sustained or will no longer have long time sustainability.

Discussing on the impact of deregulation, Omowa (2010) argued that it has spate up high level of importation of goods thereby making the nation to support the economies of foreign nations with large scale importation of manufactured goods which explained wide spread unemployment in the country. He concluded that deregulation will worsen the poverty level of the citizens. While, Olaitan, (2009) claimed that deregulation as a policy exacerbates the suffering of the people.

Deregulation weather from the point of view of the persimist or advocacy, deregulation command the elimination or reduction of government stringent regulations concerning financial market, trade and investment. Deregulation is a reform that came into being with the goal of stimulating economic performance (Ernest \& Young, 1998). The overall proposal is to relieve government from the burden of financial pipe drain that is associated with financingpublic utilities and the removal of government stringent control that provides environmental incentive for private individual that are most efficientin the area by promoting healthy market competition in free market environment. Indeed, deregulation as removal of government control is not totally applicable to tertiary institutions because the Federal government in spite of deregulation of tertiary institution is still playing the role of unempire judge in the regulation of quality in Nigerian universities through the instrumentality of NUC and NBTE in the case of polythenics and colleges of education.

\section{Theoretical Framework}

Descentralization theory is adopted in providing theoritical explanation to this study. The concept implies the breaking down of government machinary into lower levels of government with constitutional reponsibility to function within its allotted sphere to ensure easy and effective adminisration. In this regard,power is located in more than one level of government; federal,state and local government authorities. This form of power division between the central authority and its constituent or subordinated units is akin to federal system of government, in which power sharing is capable of stimulating democratic participation among the grassroot populace who are the most beneficiary of this power sharing arrangement, since it provides them government's proximity. Iyoha(1999), identified elements of descentralization as; devolution,local administration, field administration,delegation,power,authority and deconcentration. Gboyega,Obiyan and Mimiko(2008), collapsed the above variables of descentralization into two broard vesslles as;devolution and deconcentration of power. While devolution concerns transferring of some powers fron central government to its subordinate units, deconcentration is about the transferring of some administrative responsibilities from the central to administrativeoutfits.

To a large extent, the recipient of devolutory authority borders on right while that of deconcentration borders on priviledge(Iyoha,1999). In this case, devolutory authority enjoys more freedom of independent decision making within its jurisdition while deconcentrated authority enjoy such freedom in a related term. Though this theory has the advantage of; adaptation to local situation based on issues that required decision suitable for local circumstances as well as plateform for promoting efficiency and effectiveness in an organization or matter of specific interest, it is also criticized for its expensiveness since it involves various levels of government and authorities(Gboyega,Obiyan and Mimiko,2008) 
The analysis of this theory is germane to the understanding of deregulation policy from the point of view of its efficiency and democratic participation. Nigerian Market failure in are of public utilities that were serving as financial pipe-drain of government budgetory allocation with little or nothing in return in terms of its output, made the government to resort to the policy of deregulation by giving license to private individual who perhaps are more efficient in providing such services to the public. Also, it will offer individual the opportunity to actively participate in business ownership in the state rather than government monopoly.

The removal of government stringent rules from investment areas will bring such investment opportunity to the level of dessegregate, whereby new bodies will emerge, with the power and authority to make decision and control their business organisation instead of the other way round. This competition will bring about output maximisation in the most efficient and effective way. In Nigeria for example, students of private universities enjoy relative stability in their academic calendar coupled with high rate of output turnover when compared with public universities. These ofcourse may suffice any other organization of private ownership in Nigeria and elsewhere in the world.

\section{Objectives of the study}

The overall aim of the study was to examine the perception of the deregulation of the tertiary educational sector and its implications on national development. The study focused on the following specific objectives, which were to:

1. examine the socio-economic characteristics of respondents

2. ascertain citizens' perception of deregulation of the tertiary educational system

3. ascertain the perceived influence of deregulation on the tertiary educational system

\section{Hypothesis of the study}

The following null hypothesis was tested:

Ho: There is no significant difference in the perceived impact of deregulation on the educational sector

\section{Research Method}

The study area is Edo state. The state is one of the 36 States in the country and lies in the Niger Delta region of the country. It has a population of about 2,172,008based on the 1991 national population census. The state has many tertiary institutions,comprisis of five universities, four polytechnics, two colleges of Education and Institute of Continuing Education (degree awarding institution)

The study utilized the survey research design. The population of the study is based on adult residents of the State. In drawing the sample of this study, multi-stage random sampling and purposive sampling techniques were adopted. Respondents were drawn from two ( Edo south and Edo central senatorial districts)of the three senatorial districts in the State. Senatorial districts are composed of local governments (LG); three local governments were randomly sampled from each senatorial district making 6 LG sampled for the study. The selected LGA were Uhunmwode, Ovia North East and Oredo in Edo South and Igueben, Esan West and Esan Central LGAs from Edo Central.Three communities were drawn from the selected LGA making a total of 27 communities. Fifty residents in the community were sampledon house basis. In each community, 50 respondents were drawn, thus making a total of 150 participants from each local government. Total respondents sampled were 900. However, only 881 responses were retrieved due to non-or incomplete responses.

Primary data were collected from the respondents by means of validated research instrument/questionnaire. Research assistants were used for the purpose.Data obtained were analyzed using frequency distribution and mean while the study hypothesis was tested using Friedman test. This test is a non-parametric test and is an alternative to the Analysis of Variance. It compares the significance of the difference between related variables whose data measurement level is ordinal.

\section{Measurement of variables}

Key variables assessed in this study were measured as follows:

\section{Perception of government deregulation policy on tertiary educational system}

This was measured by asking respondents to indicate their extent of agreement or disagreement on question items relating to their perception. Their response was coded on a 5 point Likert scale with the following range: Strongly agree (coded 5); Agreed (coded 4), Undecided (3); Disagreed (coded 2); and stronglydisagreed (coded 1). The weighted mean score of 3.00 was used to determine agreement (if score $>3.00$ ) or not (mean < 3.00) with the statements. The weighted mean score was gotten by adding together the codes (i.e. 5, 4, 3, $2 \& 1$ ) and dividing by 5 . 


\section{Perception of the Impact of Government Deregulation Policy on Tertiary Educationalsystem}

This was measured by asking respondents to indicate their extent of agreement or disagreement on question items relating to impact. Their response was coded on a 5 point Likert scale with the following range: Strongly agree (coded 5); Agreed (coded 4), Undecided (3); Disagreed (coded 2); and strongly disagreed (coded 1). The weighted mean score of 3.00 was used to determine agreement (if score $>3.00$ ) or not (mean $<3.00$ ) with the statements. The weighted mean score was gotten by adding together the codes (i.e. 5, 4, 3, 2 \& 1) and dividing by 5 .

\section{Results and Discussion}

\section{Socio-economic characteristics of respondents}

Table 1 reveals the socio-economic profile of the respondents in the study area. Most respondents were married $(83 \%)$ which was indicative of sense of family responsibility. About half of the respondents $(52.4 \%)$ had a family size of $5-8$. About $62.8 \%$ were males while $37.2 \%$ were females. In terms of age $27.2 \%$ of them were $31-40$ years old, $22.6 \%$ were $41-50$ years while $19 \%$ were $51-60 \%$ years old. Most $(83.2 \%)$ had formal education with primary education being the modal educational attainment with a percentage of $38.4 \%$. about $18 \%$ had secondary education. To a certain extend, the respondents can be considered literate and are able to appreciate government policy on the deregulation of the educational system and its impact on the system. Respondents were economically engaged with $20.7 \%$ being farmers, $17 \%$ were traders, $17.7 \%$ worked for the government while $19.8 \%$ were students. The modal monthly income range of the respondents was N60,001$80,000(25.5 \%)$

Table 1: Socio-economic characteristics of respondents

\begin{tabular}{|c|c|c|c|}
\hline & & Freq & $\%$ \\
\hline \multirow{3}{*}{ Gender } & Female & 328 & 37.2 \\
\hline & Male & 553 & 62.8 \\
\hline & Total & 881 & 100.0 \\
\hline \multirow{7}{*}{ Age range (dichotomy) } & $20-30$ & 120 & 13.6 \\
\hline & $31-40$ & 240 & 27.2 \\
\hline & $41-50$ & 199 & 22.6 \\
\hline & $51-60$ & 167 & 19.0 \\
\hline & $61-70$ & 130 & 14.8 \\
\hline & $>70$ & 25 & 2.8 \\
\hline & Total & 881 & 100.0 \\
\hline \multirow{7}{*}{ Educational qualification } & No formal education & 148 & 16.8 \\
\hline & Primary education & 338 & 38.4 \\
\hline & Secondary education & 154 & 17.5 \\
\hline & NCE/OND & 164 & 18.6 \\
\hline & $\mathrm{HND} / \mathrm{BSc}$ & 47 & 5.3 \\
\hline & Post-Graduate & 30 & 3.4 \\
\hline & Total & 881 & 100.0 \\
\hline \multirow{5}{*}{ Marital status } & Married & 731 & 83.0 \\
\hline & Single & 48 & 5.4 \\
\hline & Divorced & 25 & 2.8 \\
\hline & Widowed/widower & 77 & 8.7 \\
\hline & Total & 881 & 100.0 \\
\hline \multirow{6}{*}{ Household size } & Alone & 42 & 4.8 \\
\hline & $4 \&$ below & 152 & 17.3 \\
\hline & $5-8$ & 462 & 52.4 \\
\hline & $9-12$ & 155 & 17.6 \\
\hline & $13 \&$ above & 70 & 7.9 \\
\hline & Total & 881 & 100.0 \\
\hline \multirow{3}{*}{ occupation range } & Unemployed & 67 & 7.6 \\
\hline & Farmer & 182 & 20.7 \\
\hline & Trader & 150 & 17.0 \\
\hline
\end{tabular}


DeregulationAnd Tertiary EducationIn Nigeria: Implications For National Development.

\begin{tabular}{|l|l|l|l|}
\hline \multirow{5}{*}{} & Govt/company worker & 156 & 17.7 \\
\cline { 2 - 4 } & Others & 152 & 17.3 \\
\cline { 2 - 4 } & Student & 174 & 19.8 \\
\cline { 2 - 4 } income range (Monthly) & Total & 881 & 100.0 \\
\hline \multirow{5}{*}{} & 20,000 \& below & 169 & 19.2 \\
\cline { 2 - 4 } & $20,001-40,000$ & 85 & 9.6 \\
\cline { 2 - 4 } & $40,001-60,000$ & 192 & 21.8 \\
\cline { 2 - 4 } & $60,001-80,000$ & 225 & 25.5 \\
\cline { 2 - 4 } & $80,001-100,000$ & 132 & 15.0 \\
\cline { 2 - 4 } & $>100,000$ & 78 & 8.9 \\
\cline { 2 - 4 } & Total & 881 & 100.0 \\
\hline
\end{tabular}

\section{Respondents' perception of deregulation on tertiary educational system}

Table 2 shows respondents perception of the government deregulation policy of the educational sector. The results indicate that they felt that government deregulation of the tertiary education system is an indication of government failure to properly fund that arm of the educational sector (mean $=3.45$ ). They were of the view that if the government had invested sufficiently in the tertiary educational system there would have been no need to open up the system to private entrepreneurs. Thus, most do not agree that deregulation of the tertiary educational sector was a manifestation of government responsiveness to the current needs of the society (mean = 2.55). Though already deregulated, the general view of the respondents was that granting of licensing for operation of private universities should be stricter to ensure quality standard. They equally did not feel it should be encouraged as they saw it as an excuse for the government to neglect the development of public universities (mean $=2.44$ ). The researcher attempted to enquire if the initiation of the policy had political undertone. The finding in the table suggest otherwise, since with a mean score of 2.44 , most believed politics was not an underlying factor in the establishment of the deregulation policy. They also did not believe that religion was an important determinant or influence in the federal government deregulation of tertiary education system even though $14.2 \%$ felt otherwise.

Table 2: Respondents' perception of deregulation on tertiary education.

\begin{tabular}{|l|l|l|l|l|l|l|l|l|l|l|l|l|}
\hline & \multicolumn{2}{|l|}{ Strongly agree } & \multicolumn{2}{l|}{ Agree } & \multicolumn{2}{l|}{ Undecided } & \multicolumn{2}{l|}{ Disagree } & \multicolumn{2}{l|}{$\begin{array}{l}\text { Strongly } \\
\text { disagree }\end{array}$} \\
\cline { 2 - 13 } & Freq & $\%$ & Freq & $\%$ & Freq & $\%$ & \multicolumn{2}{l|}{ Fooled } & $\%$ & Freq & $\%$ & \multicolumn{2}{l|}{ Mean } & SD \\
\hline $\begin{array}{l}\text { It represents failure on the part of } \\
\text { government or inability to } \\
\text { properly fund the system }\end{array}$ & 272 & 30.8 & 186 & 21.1 & 234 & 26.5 & 44 & 5.0 & 146 & 16.6 & $3.45^{*}$ & 1.40 \\
\hline $\begin{array}{l}\text { Licensing should be made more } \\
\text { stringent }\end{array}$ & 51 & 5.8 & 226 & 25.6 & 605 & 68.6 & & & & & $3.37 *$ & .59 \\
\hline $\begin{array}{l}\text { NUC should pay closer attention } \\
\text { to monitoring of the schools } \\
\text { (accreditation exercise) }\end{array}$ & 96 & 10.9 & 170 & 19.3 & 345 & 39.1 & 104 & 11.8 & 167 & 18.9 & 2.91 & 1.22 \\
\hline $\begin{array}{l}\text { It shows government } \\
\text { responsiveness to the current } \\
\text { needs of the society }\end{array}$ & & & 275 & 31.2 & 1 & .1 & 539 & 61.1 & 67 & 7.6 & 2.55 & 1.01 \\
\hline It should be encouraged & & & & 555 & 62.9 & 164 & 18.6 & 163 & 18.5 & 2.44 & .79 \\
\hline $\begin{array}{l}\text { Deregulation has political } \\
\text { undertone }\end{array}$ & & & & 555 & 62.9 & 164 & 18.6 & 163 & 18.5 & 2.44 & .79 \\
\hline It has religious undertone & 28 & 3.2 & 97 & 11.0 & 96 & 10.9 & 134 & 15.2 & 527 & 59.8 & 1.83 & 1.18 \\
\hline
\end{tabular}

*Agreed (mean > 3.00)

\section{Table 3: Perceived Influence ofDeregulation onTertiary Educational System}

Table 3 shows that the deregulation of the tertiary education system has some impact on the economy. The findings of the study as shown in the table revealed that it has increased students enrolment or admission into tertiary institutions in the country (mean $=4.58)$, improved infrastructural development $($ mean $=4.00)$, increased employment opportunities as more Nigerians are working in the newly established private universities (mean $=3.94)$, improved international rating of tertiary institutions (3.94). These represent the perceived positive impact. Unfortunately, the results also indicate that respondents felt it had impacted negatively on the nation tertiary education. These perceived negative impacts borders on increased unemployment among the 
graduates $($ mean $=3.99$ ) giving the high turnover rate of graduates as a result of increased number of universities in the country.

Respondents view was that there is now an increase in number of graduates without corresponding increase in industrial development, thus the labour market is increasing without sufficient companies to absorb them.The respondents equally felt that the increase in private universities have resulted in Compromised admission process/procedures by private tertiary institutions (mean $=3.91$ ). This is done to encourage students' admission as well as to build sufficient capital to maintain the operations of the institution. Running a private university is a very expensive and capital intensive venture and if the critical number of students are not admitted the institution will go bankrupt. This has led many to evolve questionable mechanisms in the admission process to get as many students as possible into their institution. One of the negative fallout of deregulation policy is also increased in school fees (mean = 3.66). This is particularly noticeable in public tertiary institutions where school fees have gone up by over $300 \%$ since the inception of deregulation policy. There have been cases were some students have dropped from school because of inability to afford the fees.

To meet up with the hike in fees students engaged in different activities to source for funds to pay their tuition fees. This coroborrates with the finding of Omoike and Gbinigie(2005), that deregulation leads to increase in school fees which at the long run will result to drop-out. Respondents observed that since deregulation, there has been increased in industrial action by staff of the public tertiary institutions. Possible explanation for this is that some private institutions are well funded though recently established. Some of them possess state of the arts facilities lacking in many public tertiary institutions. Thus, the public staffare thus compelled to engage their employer (the government) to show more commitment to the development of the tertiary education system. Unfortunately in Nigeria this usually takes the form of industrial strike action since that appears to be theonly language the government can understand.

Table 3: Perceived Influence of Deregulation onTertiary Educational System

\begin{tabular}{|c|c|c|c|c|c|c|c|c|c|c|c|c|}
\hline & \multicolumn{2}{|c|}{$\begin{array}{l}\text { Strongly } \\
\text { agree }\end{array}$} & \multicolumn{2}{|c|}{ Agree } & \multicolumn{2}{|c|}{ Undecided } & \multicolumn{2}{|c|}{ Disagree } & \multicolumn{2}{|c|}{$\begin{array}{l}\text { Strongly } \\
\text { disagree }\end{array}$} & \multicolumn{2}{|c|}{ Pooled } \\
\hline & Freq & $\%$ & Freq & $\%$ & Freq & $\%$ & Freq & $\%$ & Freq & $\%$ & Mean & SD \\
\hline Increased students enrolment & 661 & 74.9 & 97 & 11.0 & 99 & 11.2 & 21 & 2.4 & 4 & .5 & $4.58 *$ & .82 \\
\hline $\begin{array}{l}\text { Improved Infrastructural development of } \\
\text { public institutions }\end{array}$ & 2 & .2 & 879 & 99.7 & & & 1 & .1 & & & $4.00 *$ & .08 \\
\hline $\begin{array}{l}\text { Increased unemployment among } \\
\text { youths/graduates }\end{array}$ & 3 & .3 & 874 & 99.1 & & & 1 & .1 & 4 & .5 & $3.99 *$ & .22 \\
\hline $\begin{array}{l}\text { Increased employment opportunities as } \\
\text { university staff }\end{array}$ & 240 & 27.2 & 350 & 39.7 & 291 & 33.0 & 1 & .1 & & & $3.94 *$ & .78 \\
\hline $\begin{array}{l}\text { Improved international rating of tertiary } \\
\text { institutions in the school }\end{array}$ & 240 & 27.2 & 350 & 39.7 & 291 & 33.0 & 1 & .1 & & & $3.94 *$ & .78 \\
\hline $\begin{array}{l}\text { Compromised } \\
\text { process/procedures by private }{ }^{\text {admission }} \\
\text { institutions }\end{array}$ & 392 & 44.4 & 214 & 24.3 & 116 & 13.2 & 123 & 13.9 & 37 & 4.2 & $3.91 *$ & 1.23 \\
\hline Hike in School fees & 226 & 25.6 & 284 & 32.2 & 279 & 31.6 & 35 & 4.0 & 58 & 6.6 & $3.66^{*}$ & 1.10 \\
\hline $\begin{array}{l}\text { Increased industrial action by public } \\
\text { tertiary institutions (staff) }\end{array}$ & 228 & 25.9 & 336 & 38.1 & & & 318 & 36.1 & & & $3.54 *$ & 1.22 \\
\hline $\begin{array}{l}\text { Salary discrepancies between private and } \\
\text { public tertiary institutions }\end{array}$ & 37 & 4.2 & 122 & 13.8 & 116 & 13.2 & 215 & 24.4 & 392 & 44.4 & 2.09 & 1.22 \\
\hline $\begin{array}{l}\text { Labour market discrimination in } \\
\text { employment of public and private } \\
\text { institutions' graduates }\end{array}$ & 28 & 3.2 & 97 & 11.0 & 96 & 10.9 & 134 & 15.2 & 527 & 59.8 & 1.83 & 1.18 \\
\hline $\begin{array}{l}\text { Improved academic performance of } \\
\text { students }\end{array}$ & & & & & 251 & 28.5 & 215 & 24.4 & 416 & 47.2 & 1.81 & .85 \\
\hline $\begin{array}{l}\text { Increased in remuneration of university } \\
\text { staff }\end{array}$ & & & & & 251 & 28.5 & 215 & 24.4 & 416 & 47.2 & 1.81 & .85 \\
\hline Improved moral standard of students & & & & & 227 & 25.7 & 241 & 27.3 & 414 & 46.9 & 1.79 & .83 \\
\hline
\end{tabular}

*Agreed (mean > 3.00)

Test of Difference in Perceived Impact of Deregulation on Tertiary Education

Friedman test was employed to test if significant differences exist in the perceived impact of deregulating the tertiary education system. The findings, presented in Table 4, revealed that significant 
difference exist among the perceived impact (Chi-square $=5907 ; \mathrm{p}<0.001)$. In other words respondents felt some consequences of the deregulation were more significantly serious than others. Thus such impact as increased student enrolment (mean rank $=10.96$ ) was considered to be the most significant, followed by improved infrastructural development (9.12), increased unemployment among graduates (9.10). These were considered more significantly serious relative to such impact as improved moral standard of students (3.50), increased remuneration of university staff (3.64) and academic performance of students as a result of proliferation of tertiary institutions (3.64).

Table 4: Test of Difference in Perceived Impact of Deregulation onTertiary Education

\begin{tabular}{|l|l|}
\hline & Mean Rank \\
\hline Increased students enrolment & 10.95 \\
\hline Improved Infrastructural development of public institutions & 9.12 \\
\hline Increased unemployment among youths/graduates & 9.10 \\
\hline Compromised admission process/procedures by private tertiary institutions & 9.08 \\
\hline Increased employment opportunities as university staff & 8.88 \\
\hline Improved international rating of tertiary institutions in the school & 8.88 \\
\hline Hike in School fees & 8.24 \\
\hline Increased industrial action by public tertiary institutions (staff) & 8.07 \\
\hline Salary discrepancies between private and public tertiary institutions & 4.22 \\
\hline Labour market discrimination in employment of public and private institutions' graduates & 3.68 \\
\hline Improved academic performance of students & 3.64 \\
\hline Increased in remuneration of university staff & 3.64 \\
\hline Improved moral standard of students & 3.50 \\
\hline
\end{tabular}

Chi-Square $=5907.180 ; d f=12 ; p<0.001$

\section{Conclusion and Recommendations}

The study investigated the perceived impact of government deregulation of the tertiary education system in Nigeria. Edo state was taken as the case study. A total of 881 respondents provided responses that were used for analysis and these were sampled from the two senatorial districts in the State. Data analysis was accomplished using frequency tables, mean, standard deviation and Friedman test.

The respondents felt the enactment of the policy was borne out of government inability to fund tertiary education development (mean $=3.45)$ and called for stricter issuance of licensing (mean $=3.37)$. In the opinion of the respondents, deregulation of the tertiary educational system has had important positive and negative impacts on the educational sector. Notable positive impacts includedecreased students enrolment or admission into tertiary institutions in the country $($ mean $=4.58)$, improved infrastructural development $($ mean $=4.00)$, increased employment opportunities (mean $=3.94$ ) and improved international rating of tertiary institutions (3.94).These perceived negative impacts of the deregulation bordered on increased unemployment among university graduates (mean $=3.99$ ) and compromised admission process/procedures employed by private tertiary institutions (mean $=3.91$ ). Friedman test showed that significant differences exist in the perceived impact of the deregulation of the tertiary education sector.This increased unemployment among university graduates as revealed in this study coroborates the theoritical explanation earlier presented in this study; that descentralization theory in form of deregulation, nurtures competition that dubled organizational output. When university output dubled, it means a conrespondent increase in the number of graduates turn-out.

Based on the findings the following recommendations are proposed:

The Ministry of Education, under the ages of the Nigerian University Commission, should be more stingent in the issuance of operating license to private entrepreneur interested in establishing a tertiary institution.

The ongoing regulation of quality by National Universities Commission (NUC) and National Board for Technical Education (NBTE) in the established tertiary institutions in the country is commendable and should be maintained while monitoring officers of the agencies should be encouraged to maintain professionalism in the conduct of the exercise. Of particular importance is the admission process which many believed had been compromised by private establishments seeking to have students. Regulation to achieve quality and efficient production is in corollary with the theoretical explanatory paradigm adopted in this study.

It is reported that less than 5\% of university graduates in Nigeria get employment after graduation. This suggests a gap between the manpower development and industrial growth.Thus, the government should seek to expand the industrial development to encourage absorption of the newly trained manpower (the graduates). Also, 
universities should incorporateentrepreneurship trainings in their curriculum to empower graduates to pursue self- employment and not to depend on white-collar job.

Although private and government institutions cannot be told to reduce their school fees rate since quality education is expensive, however, the government and private companies can be encouraged to provide scholarship to university students as part of their corporate social responsibility.

\section{References}

[1]. Agha, B. (2009). "Deregulation: No Option for now" Tribune, October 20:47

[2]. Ahmad, Shabbir, 2006, Corporate Governance and Performance of Commercial Banks inPakistan, Paper presented in 23rd Symposium on Money, Banking and Finance,Lille, France

[3]. Arthur, S \&Sheffrin, S.M (2002). Economics Principles in Action.New Jersey: Pearson Prentice Hall, 415pp

[4]. Burki, Abid A., and G.S.K. Niazi 2003, The Effects of Privatization, Competition andRegulation on Banking Efficiency in Pakistan, 1991-2000, StrengtheningRegulation Policy and Practice. Manchester: University of Manchester,Chancellors Conference Centre

[5]. Demurger S. (2001). "Infrastructure development \& Economic Growth: An Explanation of Regional Disparities in China"Journal of Comparative Economies 29:95-117

[6]. Gbosi, A. N. (2004). Monetary Economics and the Nigerian Financial System. Ibadan: Olorunshola Publishers, 388pp.

[7]. Gboyega, A; Obiyan, S and Mimiko, F (2008).Exam Focus: Government for WASSCE \&SSCE, Ibadan, University Press. 116pp

[8]. Harris, C (2003) "Private participation in infrastructure in Developing countries Trends, Impacts Policy lessons"World Bank working paper No 5 Washington DC, The World Bank/International Bank for reconstruction \& Development

[9]. Iyoha, F.E. (1999). Local Government and Rural Development:Bottom-Up Perspective.Benin-City: Sylva Publication Ltd., 370pp.

[10]. Iimi, Atushi, 2003, Efficiency in the Pakistani Banking Industry: Empirical Evidenceafter the Structural Reform in Late 1990s.Pakistan Development Review, 42:1,41-57

[11]. Oluleye, F.A. (2005). "Deregulating an Economy: The Theoretical Perspective". In Akpotor, A. S;Omohan M. E; Iganiga B. O; Aigbokhavbolo, O. M. and Afolabi, A. O. (eds) Deregulation and Globalisation In Nigeria: Issues And Perspectives. Ekpoma, AAU Publishing House: 15-33.

[12]. Omoike, D. \&Gbinigie, O. U. (2005). "Deregulation Of education In Nigeria: Implications For Access To University Education" In Akpotor, A. S; Omohan M. E; Iganiga B. O; Aigbokhavbolo, O. M. and Afolabi, A. O. (eds) Deregulation and Globalisation In Nigeria: Issues And Perspectives.Ekpoma: AAU Publishing House, 127-237.

[13]. Onobun, E. O.\&Obadan, D. A. (2005). "Deregulation And Poverty In Nigeria" In Akpotor, A. S; Omohan, M. E; Iganiga, B. O; Aigbokhaevbolo, O.M. And Afolabi, A. O.(eds) Deregulation And Globalization In Nigeria: Issues And Perspective. Ekpoma: AAU Publishing House, 181-196.

[14]. Onwuka, E.C; Asemota, A. and Arowoshegbe, A.O.(2005) ."Deregulation-Poverty Alleviation Nexus in Nigeria" In Akpotor A. S; Omohan, M. E; Iganiga, B. O., Aigbokhaevbolo, O. M. And Afolabi, A. O. (eds) Deregulation And Globalization In Nigeria, Issues And PerspectivesEkpoma: AAU Publishing House: 225-238.

[15]. Olaitan, T. (2009). "The Evils of Deregulation"retrieved on www.google.com, December, 2010.

[16]. , J. (2010). "Deregulation as National Albatross" Tribune, January 4:18

[17]. Olukoya, O. (2009). "Mass Sack at OlabisiOnibanjo University" Tribune, November 10:1

[18]. Ubhenin, O. E. (2012) State Policy and Economic Development. Benin City, Dos-Nitas Global.205 PP 